\title{
KNOWLEDGE AND ATTITUDES OF HEALTH CARE WORKERS FROM THE PRIMARY HEALTH CENTRE IN INĐIJA, SERBIA ON PROFESSIONAL EXPOSURES TO BLOOD-BORNE INFECTIONS
}

\author{
Zdenko GAJIĆ ${ }^{1}$, Smiljana RAJČEVIĆ , Predrag ĐURIĆ ${ }^{2}$, Svetlana ILIĆ , and \\ Tihomir DUGANDŽIJA ${ }^{3}$ \\ Primary Health Centre, Indija ${ }^{1}$, Institute of Public Health of Vojvodina ${ }^{2}$, Institute of Oncology of Vojvodina ${ }^{3}$, \\ University of Novi Sad Faculty of Medicine, Novi Sad, Serbia \\ Received in May 2012 \\ CrossChecked in September 2012 \\ Accepted in October 2012
}

\begin{abstract}
Exposure to blood-borne infections (HIV, hepatitis B, hepatitis C) poses a serious risk to health care workers (HCWs). The aim of this cross-sectional study was to determine the level of knowledge and attitudes on occupational exposure in primary health care. In 2009, a total of 100 health care workers from the Primary Health Care Centre in Inđija, Autonomous Province of Vojvodina, Serbia were included in the study. The results suggested that the health care workers who participated in the survey possess basic knowledge about blood-borne virus transmission routes. Most incorrect answers were related to the transmission of blood-borne viruses by tears, saliva, urine and stool. This study also demonstrated that health workers tend to unrealistically estimate the risk of HIV infections. As for the level of education about the prevention and control of blood-borne infections, $49 \%$ of the participants had never had any education on this topic, while $22 \%$ had been educated during the last five years. Around $75 \%$ consider education on blood-borne infection and protective measures at work unnecessary.
\end{abstract}

KEY WORDS: blood-borne virus, health personnel, professional risk, risk perception

Despite the fact that professionally acquired bloodborne infections (HIV, hepatitis B, hepatitis C), or BBIs, can be contravened by applying general and specific measures of prevention and control, they still bear immense importance, especially for health care services in low- and middle income countries (1-3).

In a health care setting, accidental transmissions of BBIs occur as a result of exposing the skin and mucous membrane to blood and other potentially infectious body fluids. Infections apart from HIV, hepatitis B and hepatitis $\mathrm{C}$ can also be transmitted through exposure to blood (certain viral, bacterial, parasitic and fungal diseases) (4), but HIV, hepatitis $\mathrm{B}$ and $\mathrm{C}$ are primary reasons for concern. Occupational exposure to agents that cause these infections is linked to the fear and prejudice present among health care workers. Most exposures are percutaneous, occurring after medical intervention due to improper waste disposal (5-7).

Hepatitis B is the central occupational infection afflicting HCWs. The risk of seroconversion after exposure to an HBsAg positive source is between $23 \%$ and $62 \%$, whereas the risk of a clinically manifested disease is $1 \%$ to $31 \%$. After an accidental 
percutaneous exposure to a $\mathrm{HCV}$ positive reservoir, the risk of anti-HCV seroconversion is $1.8 \%$. The average risk of HIV transmission after percutaneous injury is $0.3 \%$ and $0.09 \%$ after exposing the mucous membrane (8-9).

In 2004, the Centre for Disease Control and Prevention of the Vojvodina Institute of Public Health initiated surveying the occupational exposure of HCWs. This included creating a Provincial Registry of occupational exposure for healthcare workers. Established in 2007, the Registry encompasses an electronic database, a network of local coordinators for occupational exposure blood born viruses (BBV) in all health facilities of the Autonomous Province of Vojvodina, as well as continued education through distributing educational materials. It ultimately led to an increase in the number of health care workers who reported an exposure and sought counselling or postexposure prophylaxis.

The aim of this study was to determine the health care workers' level of knowledge and individual attitudes regarding the professional risks of exposure to blood-borne infections.

\section{MATERIALS AND METHODS}

The research was carried out as a cross-sectional study. In the period from October to December 2009, all healthcare workers working in primary health care in Inđija were invited to participate in the study. The opinion poll encompassed 100 health care workers (the 40 response rate was $40 \%$ ). Participation in the study was voluntary and anonymous. Each $\mathrm{HCW}$ was informed about the purpose of the study and signed an informed consent form.

Inđija is a town and municipality located in AP Vojvodina, Serbia. The population of the Inđija municipality is 47,204 . Its Health Centre is an institution of primary health care with physicians from different fields of medicine. The study comprised the staff employed in the Primary Health Centre in Indija: general practice, dentistry, laboratory, emergency medicine, gynaecology and occupational medicine.

Among the study participants, women made up for $84 \%$ and men $16 \%$ (Table 1). As for the level of education, $22 \%$ were physicians, $11 \%$ health care workers with middle school and $67 \%$ technicians. The youngest participant in the study was 19 , while the oldest 62 . The average age was 43.19 years. The largest number of participants (34\%) had a work experience of 20 to 29 years.

Table 1 Demographic characteristics of participants

\begin{tabular}{ll}
\hline Characteristics & Participants / \% \\
\hline Sex & 16 \\
\hline Male & 84 \\
\hline Female & \\
\hline Age / years & 10 \\
\hline 19 to 29 & 26 \\
\hline 30 to 39 & 33 \\
\hline 40 to 49 & 31 \\
\hline $50+$ & \\
\hline Work experience / years & 20 \\
\hline 1 to 9 & 29 \\
\hline 10 to 19 & 34 \\
\hline 20 to 29 & 17 \\
\hline 30 to 35 & \\
\hline Profession & 22 \\
\hline Doctors / Dentists & 78 \\
\hline Nurses / Laboratory Technicians \\
\hline
\end{tabular}

As a research instrument, a previously created questionnaire from the Vojvodina Institute of Public Health was used, comprising 24 questions. The questionnaire covered demographic data, risk perception, preventive measures against blood-borne infections, exposure modes, transmission, and education about blood-borne viruses.

The collected data were entered into a database created specifically for this purpose. Survey data analysis encompassed descriptive and inferential statistic methods. Data were analysed applying a descriptive test, a Kruskal-Wallis test, a MannWhitney test and one-way ANOVA.

Statistical analysis was performed using SPSS 14 statistical software for Windows.

\section{RESULTS}

Over $90 \%$ of the medical staff believed they were exposed to some type of risk from blood-transmitted viruses at their work place, while $82 \%$ took part in medical interventions that implied contact with blood and other body liquids (Table 2). The average number of daily interventions that exposed the medical staff to BBIs was 66. In terms of profession, the largest average number of daily interventions was conducted by laboratory technicians and physicians.

Our study indicated that $78 \%$ of the participants carried out standard preventive measures aimed at 
Table 2 Knowledge on possible modes of transmission

\begin{tabular}{lc}
\hline Mode of transmission & Correct answers / \% \\
\hline Exposure to blood & 97 \\
\hline Exposure to sweat & 72 \\
\hline Exposure to saliva / tears & 43 \\
\hline Exposure to sperm / vaginal secrete & 43 \\
\hline Stool & 43 \\
\hline Urine & 30 \\
\hline
\end{tabular}

Table 3 Preventative measures routinely applied by participants

\begin{tabular}{lc}
\hline Type of preventative measures & Participants / $\%$ \\
\hline Standard precautions & 78 \\
\hline Additional protection if HIV, HBV, HCV status is known & 81 \\
\hline Hepatitis B vaccination & 82 \\
\hline Test each patient for HIV, HBV, HCV & 70 \\
\hline Cautious in all procedures with each patient and material & 86 \\
\hline Use of gloves & 73 \\
\hline Use of mask & 11 \\
\hline Use of safety glasses & 2 \\
\hline
\end{tabular}

Table 4 Type of exposure reported by participants

\begin{tabular}{lc}
\hline Type of exposure & Participants / \% \\
\hline Skin contact in the last twelve months & 27 \\
\hline Needle-stick injury in the last twelve months & 11 \\
\hline Cuts from sharp instruments in the last twelve months & 39 \\
\hline Contact of eye or other mucosa in the last twelve months & 15 \\
\hline
\end{tabular}

preventing infections, while $81 \%$ said that the measures differed in instances when they were aware that the patient suffered from HBV, HCV and HIV (Table 3). Around $73 \%$ used gloves as the most frequent means of protection, whereas $13 \%$ of the participants used gloves only when they were certain that the patients were infected. Around $11 \%$ always used masks, while only $2 \%$ used glasses regularly.

The study showed that $92 \%$ had at least one exposure to potentially infected blood or body fluid during the last 12 months (Table 4).

When working with patients, the most risky interventions included contact between a patient's blood and the skin of the HCW; needles; blood splashes; and finally injury from sharp instruments. In case of exposure, $93 \%$ of the participants stated that they would report the exposure to the disease prevention service, $56 \%$ would contact a counselling office and $57 \%$ would ask for information about a patient's HIV status.

Concerning safe disposure of waste, $89 \%$ of the participants dispose of it in containers with solid sides, i.e. so-called safety boxes.
According to the medical workers' opinion on basic measures for BBI prevention at the work place, $93 \%$ consider the use of gloves to be the most important preventive measure. Most incorrect answers about the modes of transmission were related to BBI transmission by tears, saliva and stool.

As for the workers' personal health regarding HIV, Hepatitis B and Hepatitis C, $92 \%$ of the participants have never been tested for HIV, $89 \%$ for Hepatitis B antigen and $91 \%$ for anti-HCV.

Concerning education about prevention and controlling blood-borne infections, $49 \%$ of the participants have never had any education on this topic, while $22 \%$ had been educated during the last five years (Table 5). Around $75 \%$ consider education on BBIs and protective measures at work unnecessary.

Although it is well-known that Hepatitis B infections pose the largest risk to medical workers and can be counteracted with some of the most efficient preventive measures, only $44 \%$ were vaccinated against Hepatitis $\mathrm{B}$, while $7 \%$ started vaccination in the last 6 months but had not yet finished it (Table 6). 
The Kruskal-Wallis test did not find any statistical significance for BBI exposure at the workplace, neither in the application of standard preventative measures nor work experience. One-way ANOVA showed a statistically significant difference between groups classified according to work experience regarding the average daily number of interventions - less experienced $\mathrm{HCWs}$ had a larger number of interventions $(\mathrm{Md}=-21,472, P<0.02$ between work experience 1 to 19 years and 20 to 29 years, $\mathrm{Md}=-20,599, P<0.03$ between work experience 20 to 29 years and 30 and more years).

The Mann-Whitney test found a statistically significant difference between HCWs with specific training regarding BBIs and those without training $(\mathrm{U}=996, P \leq 0.04)$.

\section{DISCUSSION}

During the course of the study, it was found that there are many gaps and misconceptions among Inđija's health care workers when it comes to BBIs. The World Health Organization points out that blood born infections appear in the form of occupational exposure caused by percutaneous injuries (HCV, HBV, HIV) among health care workers, with an estimated total of $16000 \mathrm{HCV}, 66000 \mathrm{HBV}, 1000 \mathrm{HIV}$ infections occurring annually (10).

It could be that the actual gravity of this problem is underestimated due to a lack of information, underdeveloped systems for monitoring or lack of data about the frequency of injuries in HCWs who work outside public health institutions (long-term care, private offices and home healthcare). Data from our study show a high perception of professional risk from acquiring blood-borne infections among $\mathrm{HCWs}$ who were in contact with blood or other fluids from infected patients. Similar studies have shown that a great number of HCWs believe that they are at risk of a blood-borne infection (11-15). The prevalence of sharp instrument injuries among $\mathrm{HCWs}$ in studies varies from $23.5 \%$ to $74 \%(6,16)$.

Our study showed that $73 \%$ of health care workers protected themselves by using gloves, $11 \%$ used masks and only $2 \%$ used glasses. What is interesting is that the HIV status of the patient changed the worker's attitude toward standard protection and procedure and that as much as $81 \%$ of workers would use additional protection if they knew the patient was HIV positive. Results also showed that the most common protective measure was wearing gloves and that there was poor adherence to other universal precautions. This could be explained by factors such as lack of time, high workloads with an inadequate staff-to-patient ratio, scarce supplies of basic safety equipment or simply insufficient education.

The results of this research indicate that knowledge concerning the risk of BBI infections in medical institutions is determined by the following factors: lack of knowledge on HIV transmission and lack of understanding about the ways HIV cannot be transmitted; lack of published manuals on occupational safety as well as the unavailability of certain protective measures.

A great number of all exposures (75\%) could easily be prevented. Most of the workers exposed themselves while recapping a needle, placing a sharp instrument at an inappropriate place or inadequately handling waste. Most of the HCWs (89 \%) disposed of medical waste in an appropriate manner, using a safety box. Some authors have stressed the importance of placing these containers near the place where a procedure is performed (17-19).

Table 5 Education of participants about BBI prevention and control

\begin{tabular}{lc}
\hline Type of education & Participants / \% \\
\hline Education in the last 12 months & 29 \\
\hline Education in the last five years & 22 \\
\hline Uneducated & 49 \\
\hline
\end{tabular}

Table 6 Hepatitis $B$ vaccine coverage

\begin{tabular}{lc}
\hline Hepatitis B vaccination & Participants / \% \\
\hline Fully vaccinated & 44 \\
\hline Started vaccination more than 6 months ago but have not finished & 7 \\
\hline Started vaccination in the last 6 months but have not finished & 5 \\
\hline Unvaccinated & 44 \\
\hline
\end{tabular}


The results of the study suggest that a significant number of HCWs think that patients should be tested for HIV, HBV and HCV, as well as that precaution with patients and various body fluids is an important measure for preventing BBIs.

When it comes to vaccination against hepatitis B, it is alarming that $83 \%$ of respondents believed vaccination to be a significant measure of prevention, but only $44 \%$ were fully vaccinated. Other studies have shown significant differences in $\mathrm{HCW}$ vaccination. The numbers range from $18 \%$ in certain African and Asian countries to $77 \%$ in Australia and New Zealand (20-23).

We should also consider the limitations of this study. One possible limitation is the bias of occupational exposure and the fact that some answers reflected the personal views of the HCWs, which often change with time.

\section{CONCLUSION}

Health care workers showed basic knowledge about the transmission of BBIs. Their workplace brings forth a significant risk of BBI transmission through injuries (sharp instruments, needles or mucocutaneous exposure). On the other hand, health care workers usually used gloves as protective equipment, and they believed that the best protection was if the patient's HIV, HBV, HCV status was known to them. This is probably why some used protective equipment with patients whose status was positive. However, this type of approach paves the way for the stigmatization and discrimination of patients. A high percentage of participants have never been tested for HIV, anti HBs or anti-HCV. Less than half of the participants were completely vaccinated against hepatitis B.

Protective equipment (gloves, masks and safety glasses) is not always available, and health workers do not use it even when it is. Despite all stated thus far, they believed they were well-protected against BBIs. When assessing their educational needs, the highest percentage of participants said they needed training precisely in those areas where they showed the least knowledge.

In order to improve the current situation, a much stronger commitment from health care institutions needs to be directed at the implementation of BBI prevention measures and periodical evaluations and trainings for health care workers and supervisors.

\section{REFERENCES}

1. Beltrami ME, Wiliams TI, Shapiro C, Chamberland E. Risk and management of blood-borne infections in health care workers. Clin Microbiol Rev 2000;13:385-407.

2. Đurić P, Brkić S, Ćosić G, Petrović V, Ilić S. Kontrola i prevencija krvnoprenosivih infekcija u zdravstvenim ustanovama [Control and Prevention of Blood-borne Infections in Health Care Facilities, in Serbian]. Novi Sad: Institut za javno zdravlje Vojvodine; 2007.

3. Đurić P, Ilić S. HIV infekcija i zdravstveni radnici [HIV Infections and HealthcareWworkers, in Serbian]. Novi Sad: Novosadski humanitarni centar; 2007.

4. Collins CH, Kennedy DA. Microbiological hazards of occupational needlestick and 'sharps' injuries. J Appl Bacteriol 1987;62:385-402.

5. Kocić B, Petrović B, Bogdanović D, Jovanović J, Nikić D, Nikolić M. Professional risk, knowledge, attitudes and practice of health care personel in Serbia with regard to HIV and AIDS. Cent Eur J Public Health 2008;16:134-7.

6. Rampal L, Zakaria R, Sook VL, Zain A. Needle stick and sharps injuries and factors associated among health care workers in a Malaysian hospital. Eur J Soc Sci 2010;13:35462.

7. Rapparini C, Saraceni V, Lauria LM, Barroso PF, Vellozo V, Cruz M, Aquino S, Durovni B. Occupational exposures to bloodborne pathogens among healthcare workers in Rio de Janeiro, Brazil. J Hosp Infect 2007;65:131-7.

8. Centers for Disease Control and Prevention. Updated US public health service guidelines for the management of occupational exposures to $\mathrm{HBV}, \mathrm{HCV}$, and $\mathrm{HIV}$ and recommendations for postexposure prophylaxis. MMWR Morb Mortal Wkly Rep 2001;50:1-54.

9. Puro V, De Carli G, Cicalini S, Soldani F, Balslev U, Begovac J, Boaventura L, Campins Martí M, Hernández Navarrete MJ, Kammerlander R, Larsen C, Lot F, Lunding S, Marcus U, Payne L, Pereira AA, Thomas T, Ippolito G. European recommendations for the management of healthcare workers occupationally exposed to hepatitis B virus and hepatitis C virus. Euro Surveill 2005;10:206-14.

10. Prüss-Üstun A, Rapiti E, Hutin Y. Sharps Injuries: Global Burden of Disease from Sharps Injuries to Healthcare Workers. WHO Environmental Burden of Disease Series No. 3. Geneva: World Health Organization; 2003.

11. Institut za javno zdravlje Srbije "Dr Milan Jovanović Batut". Percepcija rizika, stavova i znanja zdravstvenih radnika Srbije iz oblasti HIV-a I AIDS-a. II deo [Risk Perception, Attitudes and Knowledge of Serbian Health Workers from the Field of HIV and AIDS, in Serbian]. Beograd: IZJZS; 2006.

12. Anđelković V, Opačić G, Petrović N, Krtinić G, Jevtović Đ, Despotović M. Znanje, stavovi i ponašanje zdravstvenih radnika u oblasti HIV-a [Knowledge, Attitudes and Behaviour of Health Workers in the Field of HIV, in Serbian]. Beograd: Ministarstvo zdravlja Republije Srbije; 2010.

13. Hesse J, Adu-Aryee N, Entsua-Mensah K, Wu L. Knowledge, attitude and practice universal basic precautions by medical personnel in a teaching hospital. Ghana Med J 2006;40:614.

14. Hentgen $V$, Jaureguiberry $S$, Ramiliarisoa A, Andrianantoandro $\mathrm{V}$, Belec M. [Knowledge, attitude and practices of health 
personnel with regard to HIV/AIDS in Tamatave (Madagascar), in French]. Bull Soc Pathol Exot 2002;95:1038 .

15. Maupomé G, Acosta-Gío E, Borges-Yáñez SA, Díez-deBonilla FJ. Survey on attitudes toward HIV-infected individuals and infection control practices among dentists in Mexico City. Am J Infect Control 2000;28:21-4.

16. Đurić P. Uticaj programa unapređenja prevencije i kontrole krvnoprenosivih infekcija na smanjenje profesionalnog rizika radnika u zdravstvu [Impact of Programs on Improving Prevention and Control of Blood-borne Infections to Reduce Occupational Risk in Health Care Workers, in Serbian]. Novi Sad: Medicinski fakultet; 2008.

17. Edmond M, Khakoo R, McTaggart B, Solomon R. Effect of bedside needle disposal units on needle recapping frequency and needlestick injury. Infect Control Hosp Epidemiol 1988;9:114-6.

18. Haiduven DJ, DeMaio TM, Stevens DA. A five-year study of needlestick injuries: significant reduction associated with communication, education, and convenient placement of sharps containers. Infect Control Hosp Epidemiol 1992;13:265-71.
19. Makofsky D, Cone JE. Installing needle disposal boxes closer to the bedside reduce needle recapping rates in hospitals unit. Infect Control Hosp Epidemiol 1993;11:140-4.

20. Ehui E, Kra O, Ouattara I, Eholié S, Kakou A, Bissagnéné E, Kadio A. [Management of accidental exposure to blood in the Treichville teaching hospital, Abidjan (Côte-d'Ivoire), in French]. Med Mal Infect 2007;37(Suppl 3):251-6.

21. Brotheron JM, Brtlet MJ, Muscatello DJ, Campbell LS, Stewart K, McAnulty JM. Do we practice what we peach? Health care worker screening and vaccination. Am J Infect Control 2003;31:144-50.

22. Argentero PA, Zotti CM, Abbona F, Mamo C, Castella A, Vallino A. [Regional surveillance of occupational percutaneous and mucocutaneous exposure to blood- born pathogens in health care workers: strategies for prevention, in Italian] Med Lav 2007;98:145-55.

23. Philips EK, Ofori AO, Jagger J. Bloodborne pathogen exposure risk among surgeons in sub-Saharan Africa. Infect control Hosp Epidemiol 2007;28:1334-6. 


\section{Sažetak}

\section{RAZINA ZNANJA I STAVOVI ZDRAVSTVENIH RADNIKA IZ DOMA ZDRAVLJA INĐIJA, SRBIJA} O PROFESIONALNOJ IZLOŽENOSTI VIRUSIMA PRENOSIVIM KRVLJU

Infekcije virusima prenosivim krvlju (HIV, hepatitis B, hepatitis C) ozbiljan su rizik za zdravstvene radnike. Cilj istraživanja bio je da se utvrdi nivo znanja i stavova zdravstvenih radnika o profesionalnoj izloženosti u primarnoj zdravstvenoj zaštiti. Istraživanje je provedeno kao presječna studija. U istraživanju provedenom 2009. godine sudjelovalo je 100 zdravstvenih radnika Doma zdravlja Inđija. Zdravstveni radnici uključeni u istraživanje pokazali su osnovno znanje o infekcijama prenosivim krvlju i putovima prijenosa. Najviše netočnih odgovora odnosilo se na put prijenosa virusa putem suza, sline, mokraće i stolice. Ova je studija također pokazala da zdravstveni radnici pokazuju tendenciju nerealnoj procjeni rizika od infekcije HIVom. Kada je u pitanju edukacija, $49 \%$ ispitanika nikada nije imalo edukaciju iz ovog područja, $22 \%$ bilo je u prilici da se obrazuje tijekom posljednjih pet godina, dok $75 \%$ ispitanika smatra da je edukacija o infekcijama prenosivim krvlju i mjerama prevencije nepotrebna.

KLJUČNE RIJEČI: infekcije virusima, percepcija rizika, profesionalni rizik, zdravstveno osoblje

\section{CORRESPONDING AUTHOR:}

Rajčević Smiljana

Institute of Public Health of Vojvodina

Centre for Disease Control and Prevention

Futoški put 121, 21000 Novi Sad, Serbia

E-mail: smiljana.ns@sbb.rs 